\title{
The hydrodynamic response of beach nourishment in the Cancun Beach, Quintana Roo, México
}

\author{
J. C. Sanchez ${ }^{1}$, J. C. Espinal ${ }^{2}$ \& D. Moran $^{3}$ \\ ${ }^{1}$ Subgerente de Estudios Hidrográficos, GEIC, CFE, México \\ ${ }^{2} J e f e$ de Departamento de Modelos Matemáticos, GEIC, CFE, México \\ ${ }^{3}$ Departamento de Oceanografía, GEIC, CFE, México
}

\begin{abstract}
The beach nourishment project implemented in 2009 to rehabilitate the beachface and profiles of Cancun beach had been the most important project of its type in Latin America: the length of rehabilitation (10.5 kilometers), the volume of sand placed $\left(5.2 \times 10^{6} \mathrm{~m}^{3}\right)$, besides to have a dry beach in approximately one kilometer on an area where for a long time there was not a dry beach. The environmental conditions were fully fulfilled on the deposition area and also on the sand borrow areas.

The nourishment project was based on the analysis beach profiles data set, interpretation of data collected by means of oceanographic equipment, native and borrow sediment, further to the hydrodynamic and morphodynamic characterization.

This paper presents the analysis of the hydrodynamic response of Cancun Beach nourishment in Quintana Roo, México, supported on historical profiles data set analysis, seabed changes after the nourishment project and coastline evolution, in order to predict the possible changes in the morphodynamic conditions, after nourishment.
\end{abstract}

Keywords: beach nourishment, Cancun, hydrodynamic, beach profile.

\section{Introduction}

For different reasons most of the beaches in Mexico are experiencing erosion processes, depending on the particular conditions of each site, this problem will 
be presented for the special case of Cancun, the well known resort area of Mexico.

Cancun beach is important in Mexico environmentally, socially and economically. It is located on the Caribbean Sea and its beach nourishment project has to take into consideration the effect of yearly occurrence of tropical cyclones besides the anthropogenic activities such as the construction of touristic infrastructure on the dunes.

Cancun is a littoral barrier beach with a $12 \mathrm{~km}$ beach front. The origin of its native sediment is biogenic with $0.32 \mathrm{~mm}$ mean grain size. Historically, several hurricanes have stroke this beach accelerating the erosion process immensely, such as Hurricane Gilbert (1988) and Wilma (2005).

Previous studies suggest that in 1988 Cancun beach was an equilibrium and stable system with an estimated volume of 11 million cubic meters and a dry beach width between 50-60 m. After Hurricane Gilbert (1988), 5.9 million cubic meters were eroded and the beach showed a dry beach width between $35-40 \mathrm{~m}$. Before Hurricane Wilma (2005) there was a 5 million cubic meters volume of sand along the $12 \mathrm{~km}$ beachface, with a dry beach width between 25-30 m, and after Wilma remained only 400000 cubic meters of sand approximately, with a dry beach width between 5-7 m. so 4.6 million cubic meters of sand were completely swept away from the project area. In 2006 the Federal Government placed an emergency sand volume of 2.7 cubic meters in order to rehabilitate partially the main attraction of Cancun: its beautiful and white beach sand. The dry beach width varied between 35 to $40 \mathrm{~m}$ this year 2006. Between 2006 and 2009 the combined effects of hurricane waves and the anthropogenic activities continued with the erosion process. The beach front showed a dry beach width between 15-20 m. which was not attractive enough for tourism. Then the hotel owners asked the President of Mexico to help recover Cancun main attraction through the investment in the final project and the complete rehabilitation of the beach, with the placement of 5.2 million cubic meters along a $10.5 \mathrm{~km}$ beach front.

In 2009, the most important beach nourishment project in Mexico was carried out to recover the original beach conditions (1988), forming a $10.5 \mathrm{~km}$ headland beach and decreasing the sediment loss. The basis of the project is to force the hydrodynamic conditions to have profiles with gentle slope and try to maintain the sediment placed into the system.

The final project started in August 2008 and it was finished in March 2009, before the bidding process. The dredging operations started in November 2009 and were finished in February 2010. All the environmental conditions were completely fulfilled on the placement area and on the sand borrow areas.

\section{Study area}

Cancun beach is located in the state of Quintana Roo, México. It is a littoral barrier beach with 12 kilometer beachface, semi confined to the North by Punta Cancun and to the South by Punta Nizuc. Limited by the coordinates 


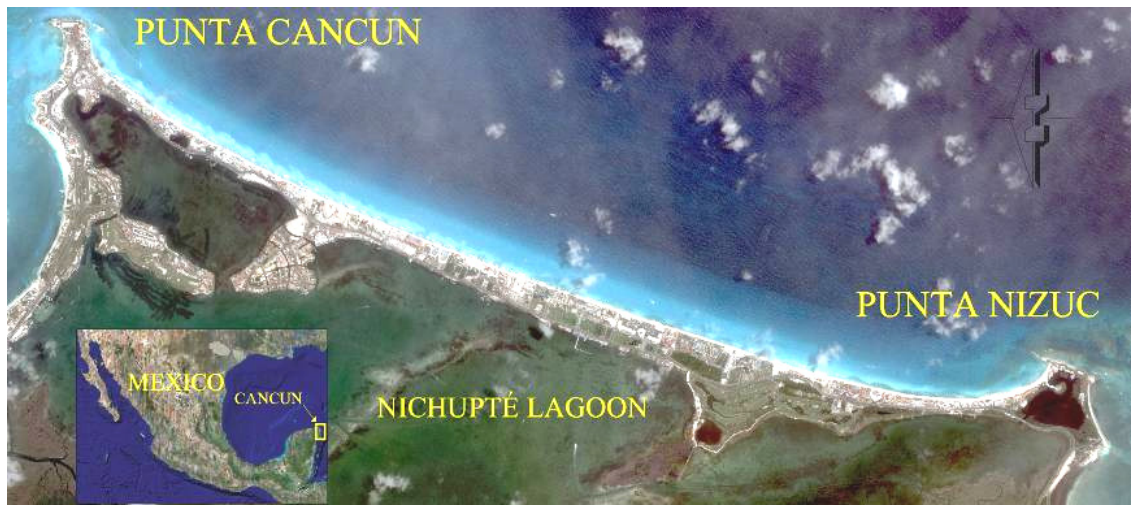

Figure 1: Cancun Beach location.

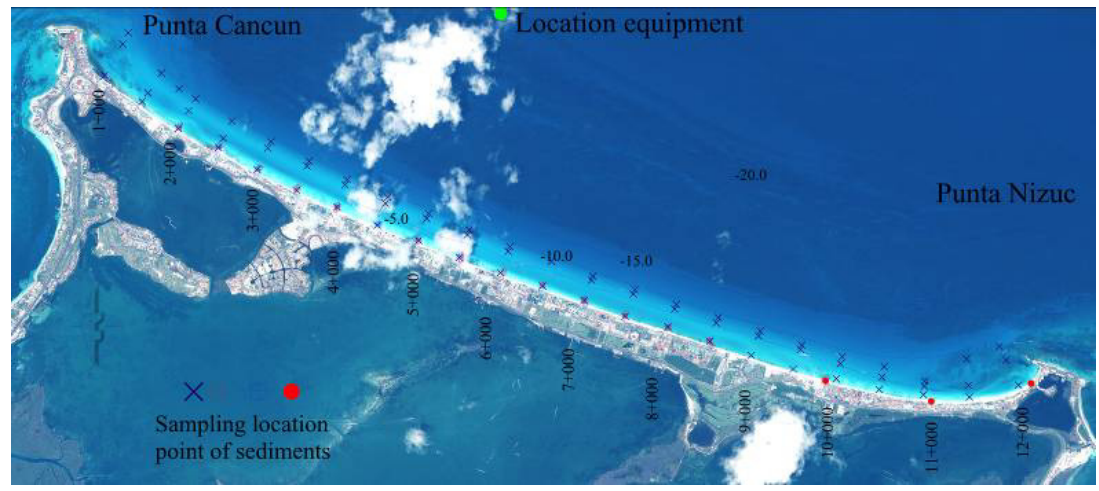

Figure 2: $\quad$ Measurements.

$21^{\circ}, 07^{\prime}, 08^{\prime \prime} \mathrm{N}, 86^{\circ}, 44^{\prime}, 25^{\prime \prime} \mathrm{W}$, to the North, and $21^{\circ}, 02^{\prime}, 07 \mathrm{~N}, 86^{\circ}, 46^{\prime}, 38^{\prime \prime} \mathrm{W}$, to the South, to the West by the Nichupté Lagoon System, as shown in Figure 1.

Site characterization was performed on previous studies and by means of collected data from measurements by the most important parameters such as topobathymetric surveys, native sediment samples, wave current measurements, and sediment samples taken on the borrow areas.

Figure 2 indicates the location equipment for wave measurements, the profile distribution along the beach and the points of sediment samples.

For a detailed characterization study the beach was divided in cross shore sections every 100 meters, starting with the $0+600 \mathrm{~km}$ section on Punta Cancun and ending on Punta Nizuc with the $12+000 \mathrm{~km}$ section. Topobathymetric surveys covered a 13 kilometers beachfront and reached the 20 meter depth contour.

Its native beach sediment is mainly of biogenic origin, with mean grain size between 0.22 and $0.55 \mathrm{~mm}$ [1]. The sediment sampling was made every 500 meters, with a starting point on $1+000 \mathrm{~km}$ section and final point in 
$12+000 \mathrm{~km}$ section. In order to cover the whole profile samples were taken on bathymetric curve levels $+1.5,0.0,-1.0,-5.0$ y -7.5 meters. All of the sediment samples were analysed in order to obtain the associated granulometric curve for each one, resulting that the lowest mean grain size values were in the northern reach with sand diameters between 0.22 and $0.3 \mathrm{~mm}$. In the Central zone mean grain size diameter varies between 0.4 and $0.65 \mathrm{~mm}$, whereas on the southern reach the mean grain size varies from 0.4 to $0.78 \mathrm{~mm}$. So our project area shows a poorly sorted sample.

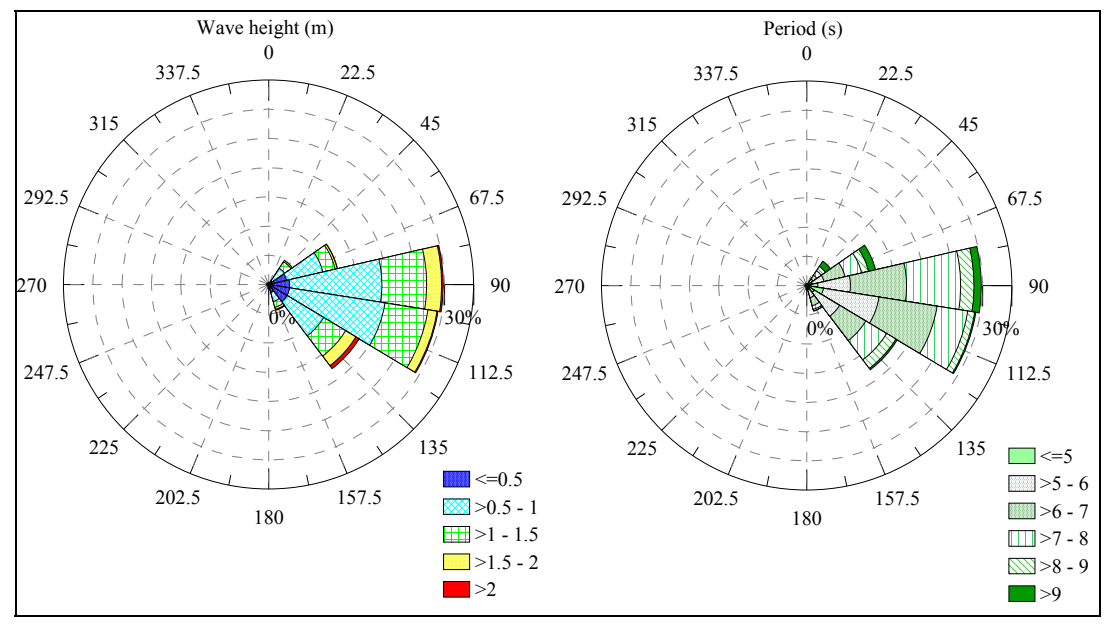

Figure 3: Wave height rose.

The wave climate was determined by means of a wave measurement instrument deployed at $23 \mathrm{~m}$ depth in front of the beachface central point, the measurement period started in September 2008 and finished in October 2010. Figure 3 shows the wave rose, observing that during the measurement period the dominant direction comes from the range 78 to $123^{\circ}$ (E, SE). The wave heights vary from 0.4 to $2.5 \mathrm{~m}$, meanwhile the mean range wave height is 0.5 to 1.0 meters, and finally the associated periods vary between 4 to 11 seconds.

\section{Cancun Beach evolution}

According to the morphodynamic state proposed by Wright and Short [2], before Hurricane Gilbert, Cancun beach could be defined as an intermediate beach tending towards the dissipative state. However, over time and due to the constant occurrence of tropical cyclones that every year strike the region, the beaches of Cancun had been evolving toward intermediate and reflective states, depending on the beach face zone. It has been observed that these changes of state are linked with erosion processes, resulting from the transport of the sediment towards the lower profile, forming longshore bars after the hurricane season. 


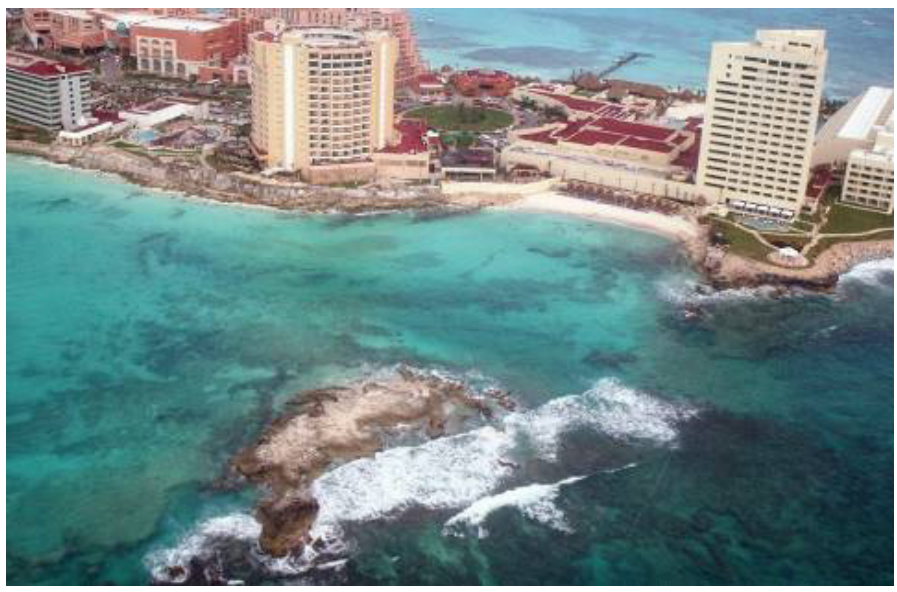

Figure 4: $\quad$ Punta Cancun, after Hurricane Wilma.

Wilma (2005) was the most dangerous meteorological event that hit the region. The hurricane was classified as category five in the Saffir-Simpson scale, and caused a considerably increment of the erosion processes, resulting in a loss of dry beach in some areas and total loss of beach width from the central to the northern zone. Punta Cancun area was the most damaged one, as shown in Figure 4.

In such a situation, an emergency beach nourishment project was performed by CFE [3]. The main object was to restore the beach profile along the 11.6 kilometers between Cancun Point and Nizuc Point. In this stage the nourishment volume to place was restricted by the available federal budget (U.S. \$20 Million), resulting in only 2.7 million cubic meters of sand, the final expected design beach width was estimated between 22 and 28 meters.

This emergency measure was not enough to rehabilitate the original beach conditions (1988, before Hurricane Gilbert).

Between 2006 and 2009 the combined effects of hurricane waves and the anthropogenic activities continued with the erosion process. The beach front showed a mean dry beach width between 15-20 m. which was not attractive enough for tourism.

During this period (2006 to 2009) several groins and detached breakwaters were built whose location and geometric characteristics increased the erosion, instead of maintaining the original beach width, as shown in Figure 5.

The beach conditions in 2009 set the stage for considering the option of a new integral project to restore the primeval status without a limited budget.

The main postulates and goals of this project were:

- To build engineering works in harmony with the prevailing environmental conditions, and

- To restore the earliest beach conditions and to keep the touristic attractiveness of Cancun. 


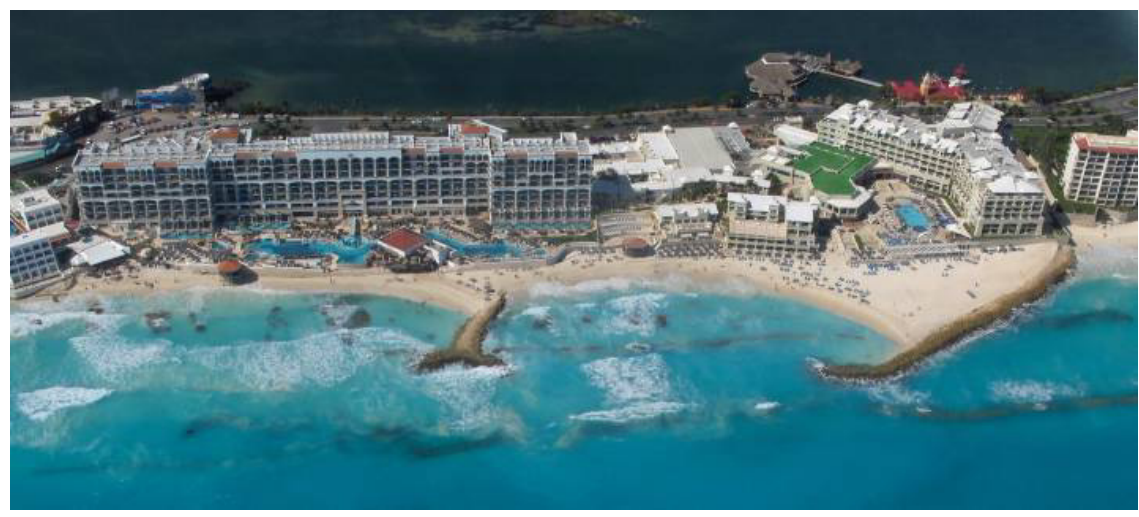

Figure 5: Jetties built without project support.

The new integral project is conceived to provide the coastal zone with enough sediment even during tropical cyclone season, because this sand cannot be replaced naturally. Furthermore, with this volume of sediment it is conceived to restore partially the lower profile, which is largely responsible for the stability of the upper profile. And finally, and not less important, to increase the dissipation of wave energy on the study area.

\section{Beach nourishment project}

Based on the characterization of wave climate, hydrodynamics, sediment transport and morphodynamics studies it is proposed to design a beach nourishment wide enough [2] supported by a groin (closure structure) located on the northern beach, on Punta Cancun.

The closure structure is built to trap the sediment carried by waves and currents action from South to North. This position of the groin was based on the hydrodynamics, sediment transport studies and the incident current conditions. The closure structure on Punta Cancun aims to restore the original continuous headland, which has been degraded by the wave action and the weathering effects.

The nourishment sand volume was calculated according to the historical site characterization. To restore the $10.5 \mathrm{~km}$ which showed to be the most damaged, it was needed to place 5.2 million cubic meters of sand. To reach this condition the width of construction had to be ranged from 80 to 100 meters on average. The beach height above mean sea level of design was 3.0 meters.

If another hurricane similar to Wilma (category four or higher according to the Saffir-Simpson scale, time of the impact and proximity) strikes the region, the sand loss in the upper profile, and the coastline retreat could be large, but the greatest amount of sediment would remain within the active beach profile. The impact of the hurricane could transport the sediment towards the lower areas of beach profile (offshore) forming longshore bars which in turn play an important role to protect the beachface and keeping the sand within the closure depth. 


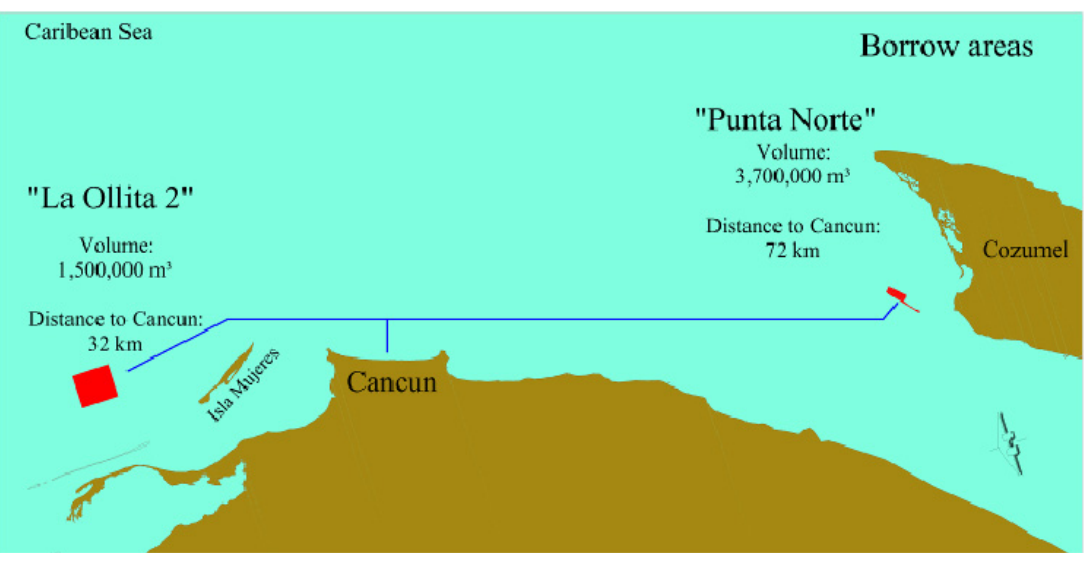

Figure 6: Borrow areas location.

The project included two borrow areas: "La Ollita 2" near Isla Mujeres and "Punta Norte" in front of Cozumel Island (see Figure 6), the main characteristics of the fill sediment in these areas was compatible with the native sand beach.

\section{Discussions}

A detailed morphological analysis of the study area was performed in order to predict the evolution of the seabed, the beach profiles and finally the coastline position under normal and extreme wave and current conditions.

Planform evolution observation aims to have an idea of the dry beach behavior through field studies. For the suitable calibration of the numerical model, it is necessary to link this information to the beach profile evolution in order to determine the coast line behavior and its morphological evolution due to the changes of profile under normal and extreme wave and current conditions.

\subsection{Seabed evolution}

From three historical detailed bathymetric surveys performed by CFE in August 2008, February and October 2010, the planform evolution was studied. The bathymetric curves for levels $0.0,-1.0$ and -5.0 were selected for each bathymetric, and then a comparison of their position was performed. Figure 7 shows the different depth positions for each bathymetric survey measurement. The seabed analysis for the North Zone "Punta Cancun" is presented in this paper because Punta Cancun was the most damaged area by Hurricane Wilma. The continuous lines represent the coastline position (bathymetric curve level 0.0), the dashes one shows the bathymetric curve level $-1.0 \mathrm{~m}$ and the composite one indicate bathymetric curve level $-5.0 \mathrm{~m}$.

For example in 2008 the coastline position (bathymetric curve level 0.0) was on the basement hotels, the bathymetric curve level -5.0 was located at a distance of 150 meter offshore, on average. 


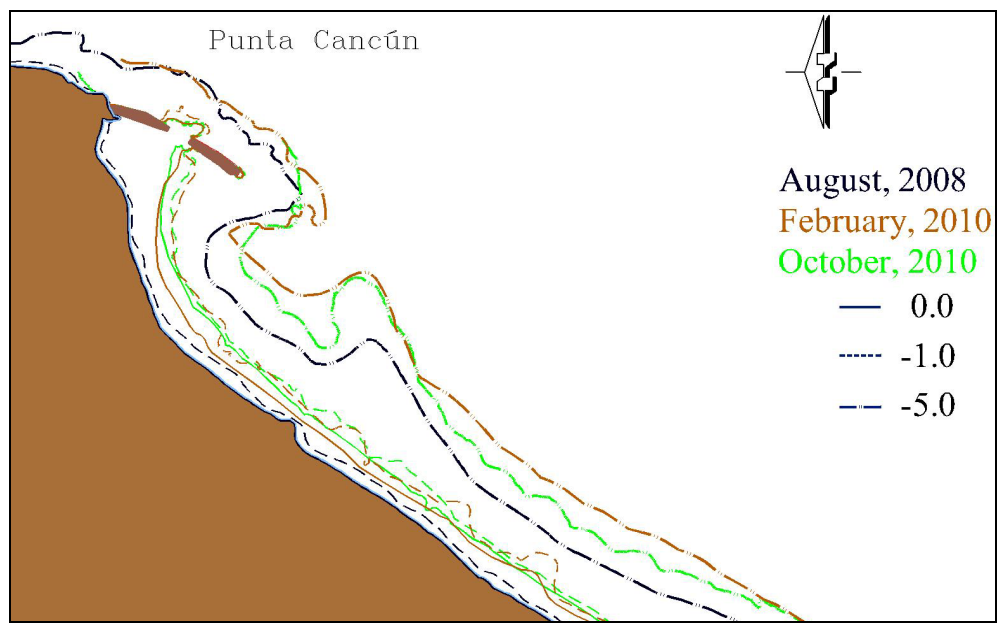

Figure 7: Seabed evolution in Punta Cancun.

As shown in Figure 7, after nourishment the coastline position moves 55 meters offshore on average, consequently also the bathymetric curve level -1.0 moved $55 \mathrm{~m}$ offshore. The most notable changes occurred in the position of the bathymetric curve level -5.0 meter, which was located about 230 meters offshore.

The placement of 5.2 million cubic meters of sand also changed the planform slope and therefore the surf zone was moved offshore, forcing to reduce the wave energy approaching the coast, and thus increasing the beach nourishment useful life.

\subsection{Planform evolution at Cancun Beach}

The planform evolution along the project area was analyzed using historical bathymetric survey measurements. Figure 8 shows the coastline position before and after hurricane Wilma, in circular and filled circular markers, both before the emergency nourishment placement; the squared marker is the coastline position in August 2008, after the emergency nourishment and before the nourishment in 2009. Finally the coastline position after nourishment project is shown in triangular markers.

Before Hurricane Wilma, 2005 the dry beach width varied between cero to 60 meters, with 28 meters on average. This year the authors observed that there were three different beach front zones:

North zone $(0+600 \mathrm{~km}$ to $4+000 \mathrm{~km})$, the dry beach width was 18 meters. Central zone $(4+000 \mathrm{~km}$ to $8+000 \mathrm{~km})$ the dry beach width varied between 20 to 30 meters, and on South zone $(8+000 \mathrm{~km}$ to $12+000 \mathrm{~km})$ the average dry beach width was 22 meters.

After Hurricane Wilma hit the region, the beach width loss was 22 meters as a mean value, transforming the three beach zones to two eroded areas: The first 


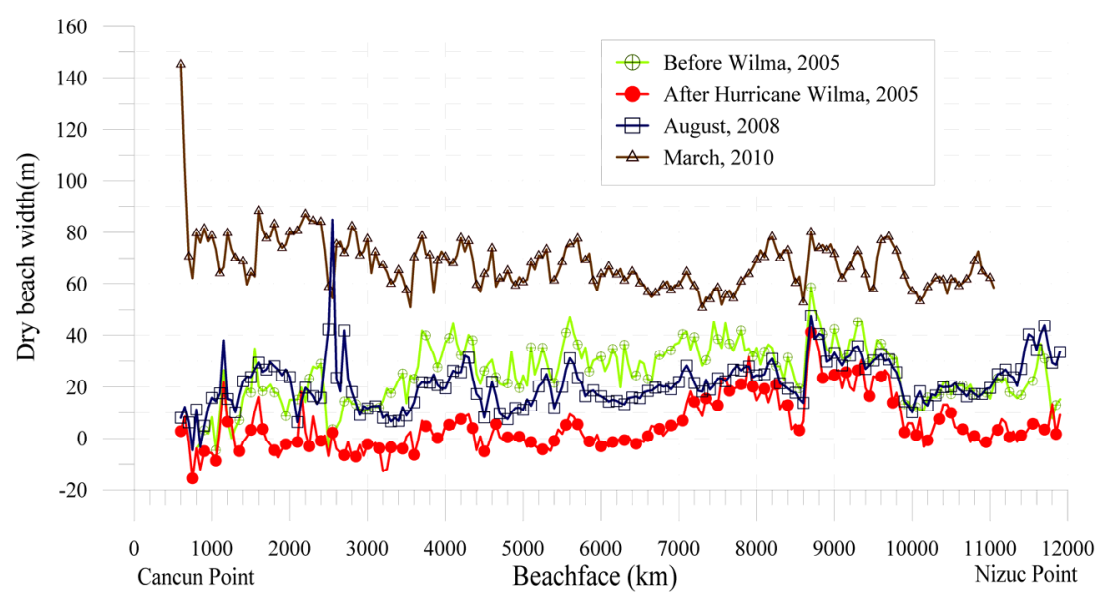

Figure 8: Coastline evolution.

one named "Severe erosion" zone covers from $0+600 \mathrm{~km}$ section to $7+000 \mathrm{~km}$ section, in this beachfront, $70 \%$ of the length without dry beach was recorded. The second area covered from $7+000 \mathrm{~km}$ to $12+000 \mathrm{~km}$ sections, with a dry beach width of 18 meters as a mean value.

After beach nourishment in 2009, mean dry beach width varied from 50 to 90 meters. Nevertheless, there was a $100 \mathrm{~m}$ beach front with dry beach more than one hundred meters and it was located close to the closure structure (Cancun Point).

At present, the North zone shows a 70 meter mean dry beach width. The Center zone has a 60 meter mean dry beach width, and the South zone exhibits a 70 meter mean dry beach width. On South the coastline shows an apparent retreat because of the longitudinal gradient: passing from 80 meter of wide in the nourishment area to 30 meter in the un-rehabilitated area.

\subsection{Beach profiles evolution}

The analysis of beach profiles has been performed since 2005, starting with measurements before and after the Hurricane Wilma occurrence. The authors present in this paper beach profiles measured after the emergency project: April (immediately after nourishment), August and December 2006. In 2008, the beach was evolving toward accelerated erosive state, reaching the same profile conditions as in 2005 .

Figure 9 shows three representative beach profiles of the beach condition: on the northern zone, the profile $0+800 \mathrm{~km}$, on center zone the profile $5+500 \mathrm{~km}$, and on south zone $10+000 \mathrm{~km}$ profile.

The analysis of evolution beach profiles from 2005 to 2008 served as a basis for understanding the beach behavior evolution, which is finally taken into consideration for the design conditions in 2009. 


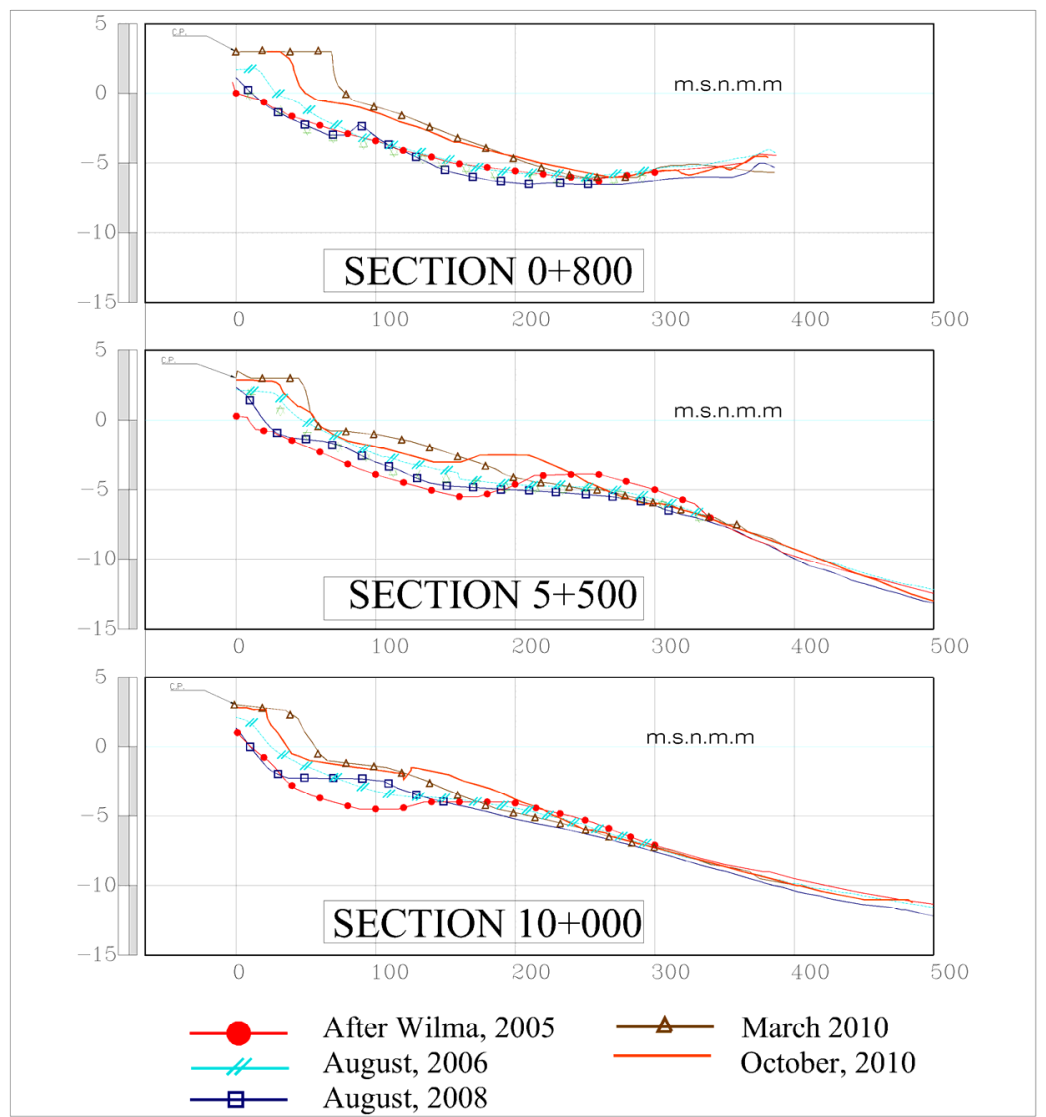

Figure 9: Beach profile at Cancun.

In 2005, after Wilma, the dry beach widths were around $20 \mathrm{~m}$, at most, as shown in fig. 8 , profile $10+000 \mathrm{~km}$. However there were areas where the beach was completely lost $(0+800 \mathrm{~km})$, reaching its maximum erosion process in these areas, with very steep slopes. The hotel foundations were a part of the beach profile.

Beach profiles analysis from 2005 to 2008 showed clearly that profiles were still reflective, particularly the profile $0+800 \mathrm{~km}$ remained practically equal during this period of time. The profiles $5+500$ and $10+000 \mathrm{~km}$ showed that a percentage of the placed material was transported to the subaerial profile. This beach profile behavior leaded the authors to establish a new project for rehabilitation of beaches, which have the ability to maintain a beach width needed for the development of tourist activities and infrastructure protection. This target could be achieved, building a beach with an intermediate morphodynamic state with trend towards a dissipative state. 
Profiles from February to October 2010 are all measured after the nourishment project, as shown in Figure 9. It is clear that after 9 months the beach profiles (post-construction) have behaved according to the project expectations, exhibiting dry beach widths between 40 and 70 meters.

So far, the beach profiles evolution has been satisfactory, maintaining a beach width and a mild beach slope within the design predictions.

On the northern zone of the beach, Punta Cancun, it was necessary to support the beach fill with a groin to trap the sediment transport from north to south, and to avoid the sand to reach the coral reefs located on the northern part between Punta Cancun and Mujeres Island.

Finally, on the southern zone, Punta Nizuc, it was not possible to place sand until this point due to severe environmental restrictions imposed by the Mexican Environmental Authorities.

\section{Conclusions}

The nourishment project was suitable for transforming the beach of Cancun into a headland, confined by Punta Cancun and Punta Nizuc. The closure structure built on Punta Cancun zone creates the hydrodynamic conditions appropriate to trap the placed sediment on this critical area, and created a protected zone, reducing the sand loss, remembering that before nourishment beach it was a zone without dry beach.

The closure groin makes possible to maintain the headland in Cancun beach for all wave climate conditions.

The beach is evolving towards a new intermediate equilibrium state very close to dissipative in some specific cases.

The estimated sand volume for the beach nourishment was enough to restore Cancun beach original conditions.

The fill sand dredged from the two borrow sand pits (La Ollita 2 and Punta Norte) was completely compatible with the native sand.

Taking into consideration the last statements the project and beach nourishment works have been considered as a successful Mexican engineering project.

And last but not least, the project fulfilled completely all the environmental restrictions imposed by the Mexican Environmental Authorities (SEMARNAT, SEMAR, SCT).

\section{References}

[1] Morán, Salles, Adame, Sánchez, Espinal, 2006. “Análisis Morfológico de las playas de Cancún”. XXII Congreso Latinoamericano de Hidráulica, Ciudad Guayana, Venezuela, octubre 2006.

[2] Wright, L. D., Short, A. D., (1984). "Morphodynamic variability of surf zones and beaches: a synthesis". Marine Geology 56, 93-118. 
[3] CFE, 2006. Proyecto Ejecutivo de Restauración y Recuperación de las playas de Cancún, Quintana Roo. Gerencia de Estudios de Ingeniería Civil (GEIC) de la Comisión Federal de Electricidad.

[4] CFE, 2009. Proyecto Ejecutivo para la Rehabilitación de playas de Cancún, Quintana Roo. Gerencia de Estudios de Ingeniería Civil (GEIC) de la Comisión Federal de Electricidad. 